DEVELOPING MEDIA BASED ON POWTOON IN

TEACHING WRITING RECOUNT TEXT FOR

GRADE VIII STUDENTS IN SMP

MUHAMMADIYAH 1 MEDAN

AN ARTICLE

Submitted in Partial Fulfillment of the Requirements for the Degree of SarjanaPendidikan

By:

MARYAM NERISSA

Registration Number: 2151121033

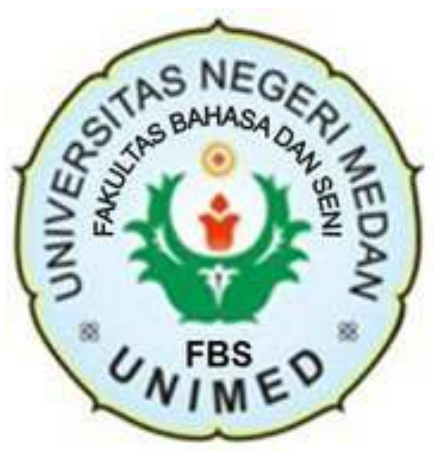

ENGLISH AND LITERATURE DEPARMENT

FACULTY OF LANGUAGES AND ARTS

STATE UNIVERSITY OF MEDAN

2020 
ARTIKEL

\title{
DEVELOPING MEDIA BASED ON POWTOON IN TEACHING WRITING RECOUNT TEXT FOR GRADE VIII STUDENTS IN SMP MUHAMMADIYAH 1 MEDAN \\ Disusun dan Diajukan oleh:
}

\author{
Maryam Nerissa \\ NIM. 2151121033 \\ Telah diverifikasi dan dinyatakan memenuhi syarat \\ untuk diunggah pada jurnal online
}

Medan, Januari 2020

Menyetujui

Dosen Pembimbing 1

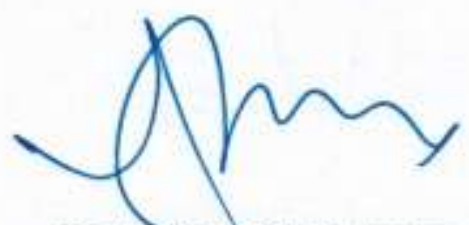

Dr. Anni Holila Pulungan, M.Hum. NIP. 197005222001122001

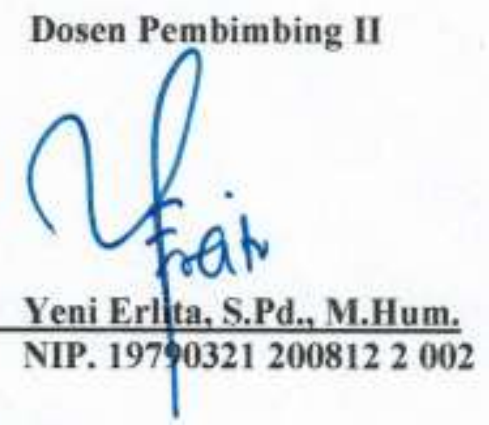

Ka. Program Studi

Pendidikan Bahasa Inggris

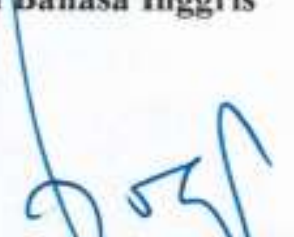

Nora Ronita Detvi, S.Pd., S.S., M.Hum. NIP.19800522 2008122003 


\title{
DEVELOPING MEDIA BASED ON POWTOON \\ IN TEACHING WRITING RECOUNT TEXT \\ FOR GRADE VIII STUDENTS IN SMP \\ MUHAMMADIYAH 1 MEDAN
}

\author{
*Maryam Nerissa \\ ***Dr. Anni Holila Pulungan, M.Hum \\ **Yeni Erlita, S.Pd., M.Hum
}

\begin{abstract}
Nerissa, Maryam. Registration Number. 2151121033. Developing Media Based on PowToon in Teaching Writing Recount Text for Grade VIII Students in SMP Muhammadiyah 1 Medan. A Thesis. English Educational Program, State University of Medan. 2019.

The study was aimed to develop media based on PowToon in teaching writing recount text for grade VIII students in SMP Muhammadiyah 1 Medan. This study was conducted by using Research and Development (R \& D) design through six stages; gathering information and data, analyzing data, designing materials, validating by experts, revising, and final product. The subject of the study was Grade VIII of SMP Muhammadiyah 1 Medan. The data were gathered by administering interview to English teacher and distributing questionnaire to 30 respondents to get the students' needs. The interview and questionnaire result prove that the students' needs English learning media which can motivate the students to understand about the recount writing. The product has been validated by experts. The result of the product was videos that contain audio-visual media to be used in mastering the recount text writing. The result of experts' validation showed that the media was an appropriate media to be used in teaching writing recount text by getting the average percentage of $95 \%$ categorized as excellent.
\end{abstract}

Keywords: PowToon, Recount Text, Research and Development (R\&D)

*Graduate Status
**Lecturer Status 


\section{INTRODUCTION}

\section{A. The Background of the Study}

Nowadays, based on 2013 Competence Based Curriculum, students are expected to master four skills in order to be able to use English communicatively. One of them is writing skill. Writing is regarded as the productive skill that students should consider the writing components by struggling, managing, and providing as the obscure aspect. Also, it can be said that writing is a process of using, decomposing, composing, modifying and creating written products as the abstract concept as well (Permendiknas: 2013).

Writing is commonly considered as the most difficult English skill for students to acquire to the readers. The difficulties in writing skill happen since the students have to produce the text by using English. Besides, there are many text types taught in Junior High School. The texts used are narrative, descriptive, recount, narrative, procedure and etc. Each text has different social function, generic structures, and language features.

Richards \& Renandya (2002:303) stated that writing is the most difficult skill for second language learners to master. It is not only caused by the difficulty on exploring the students' own ideas and interests, but it is caused by the writing's components such as planning, drafting, revising, and editing also. Students have to write about what they think in their mind and state it on a paper by using the correct procedure. Those statements above explain that good writing skill important for students, but the fact shows that the students still have difficulties in their writing ability.

The syllabus of Curriculum 2013, states that one of the genres that students learned in Junior High School is description about sensory experience on how something looks, sounds, tastes. It means that the students use their imagination and knowledge in their writing.

Based on the preliminary observation of grade VIII of SMP Muhammadiyah 1 Medan that conducted by interviewing the English teacher about the students' writing especially in recount text. In teaching learning process, the researcher also found some problems. Including the teacher uses conventional media such as pictures media, and PowerPoint media. But the media is not effective because there is no progress in students in studying recount text, included vocabulary and grammar. It causes the students have low motivation in produce good writing. Here is the result of the interview with the English teacher at the school.

: What kind of media that is used during this time in teaching recount text?

: I used pictures media and PowerPoint media in teaching recount text 
$(\mathrm{R})$

$(\mathrm{R})$

: What are the advantages and disadvantages of the media that is used?

: The advantage is students can indeed understand about this material however this medium is not able to enrich the vocabulary of the students while we know that having a sufficient vocabulary is very important in writing.

: According to you, is Audio Visual media such as video needed to help development of students in recount text?

: Very needed, because animated videos can make children interested in learning.

And here is the analysis of student's recount writing:

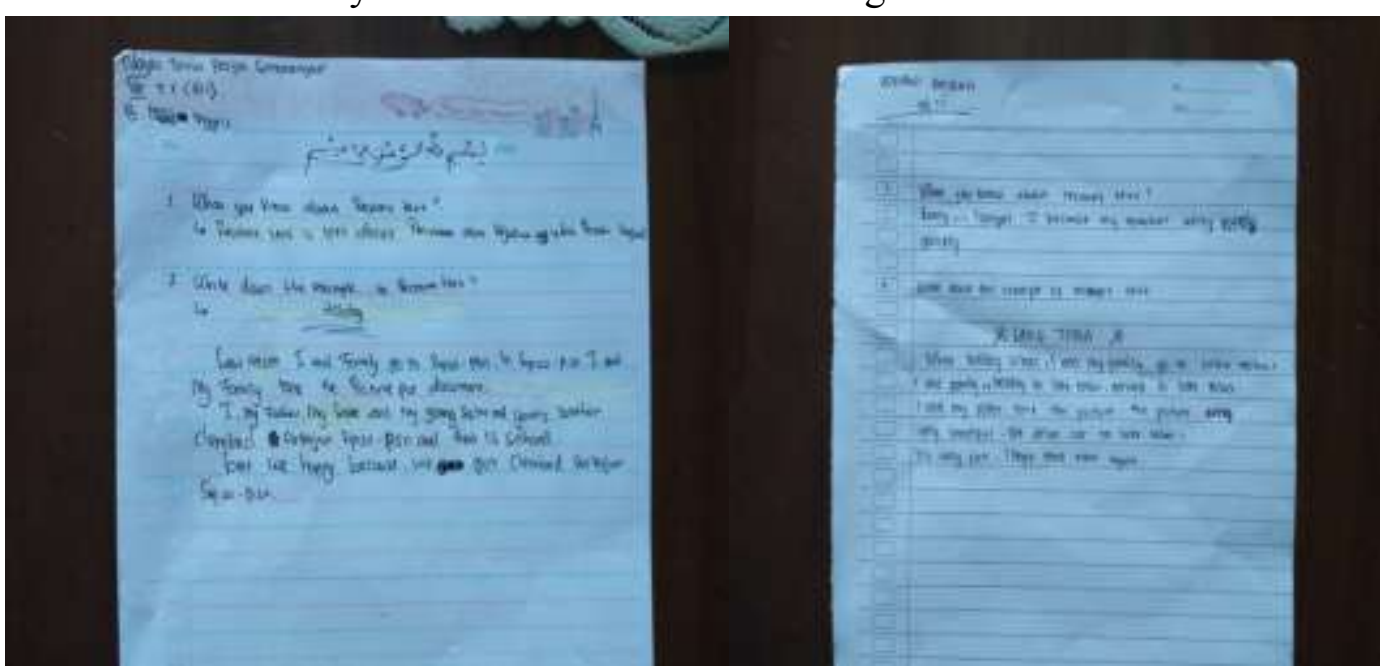

Figure 1.1.Recount Writing of Students

Based on the data above, the researcher concludes that the students didn't have a good understanding about recount text. We can see both of texts show designing the wrong generic structure. The students provide limited writing and fulfill the rules of generic structure in recount text. Besides, there is grammatical error from Amirah's writing. She has written, "verry quickly" it should be "very quickly" and always repeat words like "I and my family". And another examples of Nayla's writing is "I, my father, my sister, and my young sister and young brother clamed airterjun sipiso-piso" it should be "we climbed the Sipiso-Piso waterfall', In their writing, they always mix between English and Indonesia languages.

So from the statement above there are many media, strategies, and other ways to teach students according to the materials or potencies of the students in teaching and learning English. The students who learn English will be successful if the learning sources or media are relevant to the students' need. Besides using those ways in teaching English, the teacher may use media in teaching writing. One of them is audio visual. Igyuve (2013) states that audio visual media is tool that is used in teaching and learning process with using our sight and hearing in order to make the students acquire knowledge, skills, or attitudes. 
PowToon is included into audio visual media because it is an interactive, communicative and fun media. It makes the students interact with the teacher by using sight and hearing. PowToon is an online service to create an exposure that has a very interesting animated features including handwriting animation, cartoon animation, transition effects, and more vibrant as well as setting time line that is very easy.

\section{REVIEW OF LITERATURE}

\section{A. Theoretical of framework}

This chapter provides some important terms used in this research. These terms should be elaborated and clarified in details for the readers so that both readers and writes have the same perception.

\section{Writing}

a. Definition of Writing

Writing is one of the basic skills besides listening, speaking, and reading. Hayon (2003:93) says that writing is an active activity. It means, in doing a writing process, the writer is very active not passive, he or she try to write some ideas or information with good material based on the situation of the reader who will be read his or her writing. From explanation above, it can be concluded that writing is a process of transferring ideas, feelings, opinion, and experience.

\section{b. The process of writing}

Writing process is a procedure to an accurate text. Harmer (2004: 4-5) Defined 4 stages of writing. They are planning, drafting, editing, and final version.

\section{Recount Text}

\section{a. Definition of Recount Text}

Knapp (2005: 224) stated that Recount Text, basically it is written out to make a report about an experience of a series of related event. A recount is written out to inform an event or to entertain people. Recount Text is text function as for telling an incident in the past. Recount is to tell "what happened". Recount, tells a series of events and evaluate their significance in some way. It is also to give audience a descriptions of what occurred and when it occurred. The story recount has expressions of attitude and feeling, usually made by narrator about the events.

Hyland (2004:135) states that there are three generic structure of recount. They are:

1) Orientation : provide the setting and produces participants. It provides information about who, where, when. 
2) Record of Events : tell what happened, present event in temporal sequence. It is usually recounted in chronological order. Personal comments and/or evaluative remarks which are interspersed throughout the record of events.

3) Re-orientation : optional-closer of event. It is rounds off the sequence of events.

\section{Teaching Writing}

Brown (2007: 8) stated that teaching may be defined as showing or helping someone to learn how to do something, giving someone instructions, guiding someone in the study of something, providing someone with knowledge, and causing someone to know or understand. He also adds that teaching is guiding and facilitating learning, enabling the learner to learn, and setting the conditions for learning. Teaching writing for students who learn English is one of the important things that have to be done well because it will influence the students' ability in developing their writing ability.

\section{PowToon}

Interesting media for teaching learning in classroom need to be using suitable software. Audio - visual media need to be built by using software to organize the material of the subjects learning. In this case, writer use PowToon to organize material of subject learning. PowToon is web based animation software that can be accessed in www. PowToon.com. PowToon is also the name of the company itself which sells cloud - based software for creating animation videos and presentations. PowToon used by clicking and the general Windows PPT into more animation - based and fun - filled presentation or video. Free users can use PowToon by signing up on the website or buy the professional account for more unlimited access. The created video or presentations will directly upload to YouTube.

Gee (2004) states that the digital online universe offers plenty of opportunities for writing in a meaningful context, as it can be seen in fan communities dedicated to writing (about) games, films, books, bands. It is a whole world of opportunities for anyone to engage in multiple literate practices that allow them to actually find their own voices, whilst communicating.

PowToon animations include many kinds of media like video song as well as audio and visual instructions and it is the teacher's job to guide the learners before, though, and after each part of it. In this case teacher has to guide students through teaching learning in English classroom, especially in learning Recount text. 


\section{III.RESEARCH METHODOLOGY}

This study applies Research and Development (R \& D) research method that functioned to develop a new educational product based on the needs analysis. It adapted R \& D research method proposed by Borg and Gall (2014).

The subject of this study is the grade VIII students of SMP Muhammmadiyah 1 Medan. The reason why the researcher school is because the media that being used by the teacher is still not effective and interesting enough for students to learn or develop their recount writing skill. Based on the preliminary observation that conducted by researcher, the classroom consisted of 30 students in this school.

Collecting data, the researcher applied the combination of two strategies, using questionnaires and interview. The interview is given to the teacher and some students to seek information about the problem that they face in order to know what media that should be applied to solve the problem. While the questionnaires is given to students provided in five options by which students had to choose one of them to obtain the data about the developing of the PowToon in recount writing.

The data was collected in the form of qualitative and quantitative. The qualitative data was obtained from the interview of teacher and some students. While quantitative data was obtained from the questionnaires in form of percentage. These two forms were the references of data analysis.

The data was obtained from the interview. These data was needed to evaluation the writing media and assess the student's needs in learning writing especially in Recount text. The data was divided into two forms of data analysis, qualitative data analysis and quantitative data analysis. The data were firstly collected, and then this research was described the findings. The qualitative data was analyzed by showing the conclusion of the interview.

The questionnaires data from student changed into percentage of data, the formula like as follow:

$$
\text { Percentages } \%=\frac{\text { Total Score }(\mathrm{n})}{\text { Maximum Score }(\mathrm{N})} \times 100 \%
$$

After that, the data transforms into qualitative data with high percentage was $100 \%$ and low percentage is $0 \%$. The next is the data described qualitatively. 


\section{RESEARCH FINDINGS AND DISCUSSIONS \\ a. Research Findings}

In developing recount writing media, there were six steps need to be completed, namely (1) Gathering data and information; (2) need analysis; (3) media design; (4) validating to experts; (5) revising; and (6) final product.

\section{Gathering Data and Information}

The data and information of the potential and problem were derived from the preliminary observation. Observation was conducted in grade eighth of SMP Muhammadiyah 1 Medan. Based on the observation, teacher taught by using media such as pictures, book, and PowerPoint to support the process of teaching and learning and as the effect, the eighth grade students of SMP Muhammadiyah 1 Medan were not following the lessons, because the media not very interesting to the students and less motivate them to learn how to write in recount.

Based on the answers that the researcher got from interviewing the students, they agreed that the media that was used by the teacher was not effective enough to master the recount writing. They also had difficulties in understanding the subject and when they were asked to write something, they were confused how to start. Another problem that they faced was the English subject became one of the subjects that bored them the most cause the media that being used by the teacher did not give the goal of the study.

\section{Need Analysis}

In conducting this research, the second step needed to be complete was doing the needs analysis. The needs analysis was done by giving the grade eighth students questionnaire and were asked to answer some questions. This analysis of the students' needs later became the guidance to the researcher in developing the media of writing recount text.

\section{a. Questionnaire Analysis}

The questionnaire was administered to 30 grade eight students of SMP Muhammadiyah 1 Medan. They were given a questionnaire which consisted of 12 questions. In order to do the needs analysis, there are three categories that need to be covered, namely necessities, lacks and wants of the learners. The three categories were presented in which question number 1-4 necessities, the question number 5-8 lacks and the questions number 9-12 about wants. 


\section{b. Interview Analysis}

The researcher gave an interview to the English teacher of the eighth grade of SMP Muhammadiyah 1 Medan. It was conducted to support the results of the questionnaire analysis by the students and also to get the accurate data.

\section{The Developed PowToon as a Media}

This study is aimed to create a learning media based on the students and also the teacher needs. The researcher used the PowToon to make the learning media. The learning media that was made by the researcher is done in several steps.

1. The first step is planning; it consists of preparing the material or the script, preparing the background music and designing the story board.

2. The second step, Login at http://www.powtoon.com/

3. The third step, create the PowToon. It consists of dividing the slides, adding the text, the background, props or pictures, and characters to the slide, animate the object and timing the slides.

4. The fourth step, review the video.

5. The fifth step, export the video to YouTube.

6. The last step, download the video from YouTube to save the video for offline mode.

The learning media created by using PowToon has the results that the students and the teacher want for. The learning media consists of texts, pictures, music, and also explanations that the students need. The material is also easier to understand. The whole components exported to a video format to make it easier for the students and also the teacher to use it. Moreover, the template exists in the PowToon is editable. PowToon is really a recommended tool to make a learning media for the teacher.

In order to implement the curriculum of 2013 that applied scientific approach, there are five scientific approaches. They are observing, questioning, experimenting associating, and communicating. These steps had prepared on cover of the step of using media.

\section{a. Observing}

The first step is observing step. The observing step let the students to observe the material given in the video. The teacher, in this case, guided the students to observe two pictures that showed in the video related to recount text. e title of the specified teaching material is written as attractive as possible for students to read it. The title of 
the teaching material developed is workbook based on inquiry-based learning which are speaking material that includes four types of short dialogues.

\section{b. Questioning}

The second step is questioning. The teacher let the students asked questions related to the recount text as many as possible. The teacher can ask the students whether they understand about the recount text, or not. This process made the teaching-learning process more interactive between the teacher and students.

\section{c. Experimenting}

The third step is experimenting. Experimenting step was the most important step, because the students test out their prediction to prove the hypothesis right or wrong. The teacher can make his or her own worksheet, and the students will work individually. In this section, the teacher guided the students to analyse the example of recount text.

\section{d. Associating}

The fourth step is associating step. In this step, the teacher tried to arise the students' critical thinking. The teacher guided the students to understand more about the recount text by showing the explanation of the recount text.

\section{e. Communicating}

The last step is communicating. Communicating step was step to conclude all the knowledge that the students had been learned. In this step, the teacher asked the students to do the task. The students asked to answer some questions then asked them to write a recount text paragraph and presented in front of the class. Then, the teacher guided the students to make a conclusion about the material and also dis some corrections to the students.

\section{Validating by Experts}

The developed media firstly was judged by experts in order to make sure the quality of the product. There were 5 sections in the validating instruments; they are linguistics, process, product and content, and also layout as well as critics and suggestions. The first expert was Prof. Amrin Saragih,M.A.,Ph.D. is lecturer of English and Education Department on English and Literature study program of State University of Medan mastering into linguistics. Then, the second expert was Maulida Afriyani Lubis S.Pd who was English teacher of SMP Muhammadiyah 1 Medan. 


\section{Revising}

There were some revisions as suggested by experts.

a. Prof. Amrin Saragih,M.A.,Ph.D. suggested as follows;

The media has been designed well, but there were somethings that need to revised. The duration of the video should be longer, so the students can read the text carefully and the video will be better if using Indonesian nuance. Overall the video was already good to be used in the class.

b. Maulida Afriyani Lubis, S.Pd suggested as follows;

The learning media was already good. The video has appropriate with the students' need. But the duration of the video should be longer, so the students can read the text carefully and the all slides show is good. Overall the video was already good to be used in the teaching-learning process.

\section{Final product}

After revising the media, the researcher made some changes, such us the duration of the video is made longer than before and using Indonesian nuance in the video for the better product based on the validator comment and the media was already based on the students' needs and appropriate to be used in the teaching learning process which was able to enhance the students' enthusiasm and achievement. The video can be accessed by the following link https://youtu.be/gJj-cX0ALbA.

\section{B. Discussion}

The result of this study is to develop a learning media and to find out the needs for the eighth grade students. The researcher developed the learning media because the currently media is not appropriate and not attractive for grade VIII students in SMP Muhammadiyah 1 Medan. The media contains of main competence and basic competence as the basis and are believed to be able to ease the students in ability in writing recount text.

The developed PowToon as media were gotten by conducting the research and development stages by Borg and Gall (2014:407). The stage consisted of gathering the information needed, the lesson book used by the grade eighth students, and the media that currently used by the teacher in teaching the recount text writing.

The media developed by the researcher are already appropriate and related to the students' interest since it is based on their needs analysis. Analysing the students' need based on their interest is one of the ways to improve their learning motivation in order to increase their skills in studying English, especially writing skill. Arsyad 
(2013) stated that media is really needed to support some activities in the class. And also the learning media being used can arise students' motivation to learn using interesting and attractive media.

To get the quality of the product, the researcher gave it to the validator to be validated. The validators came from English Lecturer from State University of Medan that was Prof. Amrin Saragih,M.A.Ph.D., as the first validator and a English teacher from SMP Muhammadiyah 1 Medan that was Maulida Afriyani Lubis, S.Pd., as the second validator.The validation result consisted of 4 aspects. There are linguistics aspect, process aspect, product ad content aspect, and layout aspect. Since the average percentages of those aspects is $95 \%$.

In general the result of expert validation on PowToon is very good. Based on the validation sheets result that given to the lecturer and also the teacher, the text that is very suitable to be applied in the classroom is a recount text about experience. Because the content of the text not only can be understood easier for the students, but also the text represent the experience of the students daily life better others text given. There are only a few things that should be improved to make the learning media better.

\section{CONCLUSIONS AND SUGGESTIONS}

\section{A. The conclusions}

After analyzing the data, the researcher concluded that the students' existing writing media was not interesting, and also the media that being used by the teacher was not effective enough to make the students understand about the recount text writing. They found it was difficult to write and make a recount text which eventually brings them to be passive learners. They want to have the interesting and effective media which motivate them to learn and write the recount text. The solution for them was developing the new writing media. Developing media by using PowToon applied the R \& D phases by Borg and Gall (2014) which was simplified into, (1) Gather Data and Information; (2) Need Analysis; (3) Design Media; (4) Validate by expert; (5) Revision; (6) Final product. The score of validation from the experts was $95 \%$ and it was categorized as relevant. It means that the media were valid and appropriate to use as learning media for students. 


\section{B. Suggestions}

There were some suggestions given for the consideration the future. For the teacher, teacher should consider the students' needs in choosing the learning media. The learning process can be successful if the teacher mastered in explaining the recount text as well as using a learning media that can support them. Then, the teacher also should pay attention to kind of text that will be given to the students. For this reason, a recount text about thing is really suitable for the teacher to be used in the class, because it represented the daily life experience of students better than others text given. For the students, they can use the PowToon video as a media for them to be used in writing recount text. For the research and development, the testing should be conducted when the students were studying about writing recount text in order to get the evaluation more accurately. 


\section{REFERENCES}

Anzaku Francis 2011. Library Experts Speaks on Audio-Visual Material. A paper presented at the United Nations Educational, Scientific and Cultured Organization (UNESCO) World Day for Audio-Visual Heritage. Lafia.

Arsyad, Azhar. 2013. Media Pembelajaran. Jakarta: PT Raja Grafindo Persada

Ashaver, Doosur and lgyuve, Sandra Mwuese. 2013. The Use of Audio - Visual Materials in Teaching Learning Process in Colleges of Benue State-Nigeria.

Ashraf,A and Bilal,M.2016. ESL Learners' Writing Skills Problems, Factors and Suggestions. Journal of Education and Social Sciences.

Bakara,Carolyna Christina.2018.Developing Audio-Visual Media for Teaching Writing Descriptive Text at SMA Mardi Lestary.Medan:UNIMED

Borg,W.R and Gall.2003.Educational Research: An Introduction. Seventh Edition, New York: Longman.

Brown,H.2007.Principles of Language Learning and Teaching. USA:Longman

Daryanto, 2013.Media Pembelajaran: Perannya Sangat Penting dalam Mencapai Tujuan Pembelajaran Learning Media: Its Role is Very Important in Teaching Learning Goals. Yogyakarta: Gava Media.

Dirgayasa, I. W. 2016. College Academic Writing a Genre-Based Perspective, Jakarta:Kencana.

Dirgayasa, I.W. 2016. Genre-Based Approach: What and How to Teach and to Learn Writing. English Language Teaching.

Faridha, Noor.2018.The Effect of Video in Teaching Writing Skill Across different personality.Universitas Muhammadiyah Sidoarjo.

Fimbriani, Cholifah Siti.2016. The Use of Teaching Media PowToon to Improve Eleventh Grade of Language Class Students' Writing Ability at Sma Negeri 1 Malang.Malang.University of Muhammadyah Malang.

Gee. J. P.2011. Language and Learning in the Digital Age. New York: Routledge.

Hamalik,Oemar.1986.Media Pendidikan.Bandung. 
Hanoum,Nadia.2017.Pengaruh Penggunaan Powtoon Terhadap Hasil Belajar Siswa Pada Mata Pelajaran Ilmu Pengetahuan Sosial Terpadu Bandung.Universitas Pendidikan Iindonesia.

Harmer, J. 2004. The Practice of English Language Teaching. New York: Longman.

Harmer, J. 2007.The Practice of English Language Teaching. 4th Edition. New York: Longman.

Hayon,Yosep.2003.Membaca dan Menulis Wacana.Jakarta:Storia Grafika.

Hyland,ken.2004.Genre and Second Language Writing, The United State of America: The University of Michigan Press.

Hyland.2009.Academic Discourse: English in a Global Context. London: Continuum.

Ismail, Nour \& Seaman, Charbel.2018. The Effect of Using PowToon on Learning English as Foreign Language. Lebanon: Lebanese University.

Kementrian Pendidikan dan Kebudayaan.2013.Peraturan Menteri Pendidikan dan Kebudayaan Republik Indonesia Nomor 70 tahun 2013.Tentang kerangka dasar dan struktur kurikulum sekolah menengah kejuruan/Madrasah Aliyah Kejuruan.Jakarta:Kemdikbud.

Kementrian Pendidikan dan Kebudayaan.2013d.Peraturan Mentri Pendidikan dan Kebudayaan Nomor 65 tahun 2013 tentang Standar Proses Pendidikan Dasar dan Menengah.Jakarta:Kemendikbud.

Knapp, P., \& Watkins.2005. Genre, Text Grammar: Technologies for Teaching and Assessing Writing. Sydney: University of New South Wales Press Ltd.

Levi, W.H.,\&Lentz,R.1982.Effects of Text Illustrations: a Review of Research. Educational Communication and Technology Jornal.

Martin, J. R.1999. Factual Writing: Exploring and Challenging Social Reality. Melbourne: Deakin University Press.

Miarso.Y.2004.Menyemai Benih Teknologi Pendidikan.Jakarta:Prenada Media.

Munos,Remirez Bruno.2017. Incorporating PowToon as a learning Activity into a Corse on Technological Innovations as Didactic Resources for Pedagogy Programs. Universidad Catolica del Maule, Chile bramirez.

Neuman,W.L.2003.Social Research Methods: Qualitative and Quantitative Approaches Seventh Edition. London Person Education. 